$\xi=$ 不

\title{
Source Rock Evaluation of Paleocene Akinbo shale, Eastern Dahomey Basin
}

\author{
Dairo Victoria Abiola *, Asue David Onenu \\ Department of Physical and Earth Sciences, Crawford University, Igbesa. Nigeria \\ *Corresponding author E-mail: abioladairo@crawforduniversity.edu.ng
}

\begin{abstract}
Selected subsurface core samples of the shale of Akinbo Formation as penetrated by an exploratory well in Ibese, Eastern Dahomey basin were investigated to ascertain the quality and quantity of organic matter, the hydrocarbon potential and kerogen type.

The samples were subjected to Total Organic Carbon (TOC) and Rock Eval analyses and various cross plots were generated from the data obtained.

The TOC and Free oil content (S1) of all the shale samples range from $0.96 \mathrm{wt} \%$ to $2.82 \mathrm{wt} \%$ and $0.07 \mathrm{mgHC} / \mathrm{g}$ to $0.17 \mathrm{mgHC} / \mathrm{g}$ with $\mathrm{mean}$ values of $1.67 \mathrm{wt} \%$ and $0.11 \mathrm{mgHC} / \mathrm{g}$ respectively while the source rock potential (S2) ranges from $0.01 \mathrm{mgHC} / \mathrm{g}$ to $0.17 \mathrm{mgHC} / \mathrm{g}$ with an average value of $0.08 \mathrm{mgHC} / \mathrm{g}$. Also, the Hydrogen Index (HI) and the Oxygen Index (OI), ranges from $0.35 \mathrm{mgHC} / \mathrm{g}$ TOC to $16.7 \mathrm{mgHC} / \mathrm{g}$ TOC and $11.4 \mathrm{mgCO} / \mathrm{g}$ TOC to $38.33 \mathrm{mgCO} / \mathrm{g}$ TOC with an average value of $5.77 \mathrm{mgHC} / \mathrm{g}$ TOC and $19.04 \mathrm{mgCO} / \mathrm{g}$ TOC respectively. The Production Index (PI) and the Generative Potential (GP) range from 0.38 to 0.94 and $0.12 \mathrm{mgHC} / \mathrm{g}$ to $0.34 \mathrm{mgHC} / \mathrm{g}$ with mean values of 0.61 and $0.19 \mathrm{mgHC} / \mathrm{g}$ respectively.

The results obtained from the cross plots of HI versus OI, S2 versus TOC and TOC versus GP; It shows that the shale samples from the Akinbo Formation have good organic matter richness to generate hydrocarbon, dominantly gas prone and from a Type III kerogen.
\end{abstract}

Keywords: Shale; Organic Matter; Gas; Hydrocarbon; Kerogen.

\section{Introduction}

The buildup of any prospect in a petroleum system requires the availability of a good source rock. Source rocks are fine-grained, clay-rich siliciclastic rocks (mudstone and shale) or dark-coloured carbonate rocks (limestone and marlstone) which can generate and effectively expel hydrocarbon as a result of the abundant organic material present in them. These organic materials (carbon and hydrogen-rich organic matter) under high temperature, pressure and over time are transformed into liquid or gaseous hydrocarbons.

Source rocks are formed in places where environmental condition aids biological activities that produce high concentration and abundance of organic matter. This organic matter could be from woody plant fragments, hydrogen-rich algae or bacterial constituents and plants and animal remains.

Thus, source rock hydrocarbon-generating potential is directly related to its volume, organic richness and thermal maturity (McCarthy et al 2011).Some of these parameters were made use of in this research to assess the quality and quantity of the organic matter contained in the selected shale; and evaluation of the kerogen type to deduce the kind of hydrocarbon it can produce. This is hinged at giving more information needed to optimize development in exploration and exploitation of hydrocarbon in the Eastern Dahomey basin.

\section{Geologic setting of the study area}

A sedimentary basin is a depression in the earth crust into which sediments have been deposited and preserved over millions of year. One of these sedimentary basins is the Eastern Dahomey basin whose sediments range in age from Cretaceous to Quaternary and its thickness exceeds $2.2 \mathrm{~km}$ on the coast, in Southwestern Nigeria.

The basin extends from Southeastern Ghana through Togo and Benin Republic on the west side to the Okitipupa Ridge on the east side in the southern part of Nigeria as shown in Figure 1 (Jones and Hockey 1964; Omatsola and Adegoke, 1981). The basin thickens towards the Republic of Benin, dips down towards the Atlantic, and it is floored by crystalline basement rocks, which became faulted into a series of graben and horst.

The basin consists of Cretaceous and Tertiary sedimentary sequences that outcrop in an arcuate belt roughly parallel to the ancient coast line. The Tertiary sediments of the Dahomey basin thin out to the east and are partially cut off from the sediments of the Niger delta basin against the Okitipupa basement ridge. Sedimentation did not begin until the terminal stage of the Cretaceous whereas the earliest transgression in the Eastern part was during the Albian.

The stratigraphic setting of the Eastern Dahomey Basin has been described in detail in the works of Omatsola and Adegoke, 1981; Ako et al., 1980; Okosun, 1990; Adekeye, 2005 and Adekeye et al., 2006. The formations from the oldest to the youngest include: Abeokuta Group which is the thickest sedimentary unit and comprises of Ise, Afowo and Araromi Formations (Cretaceous), 
Ewekoro Formation (Paleocene), Akinbo Formation (Late Paleocene-Early Eocene), Oshosun Formation (Eocene) and Ilaro Formation (Eocene).
Akinbo Formation is made up of claystones rich in kaolinitic concretions and some glauconitic bands with lenses of limestone occurring at the basal part.

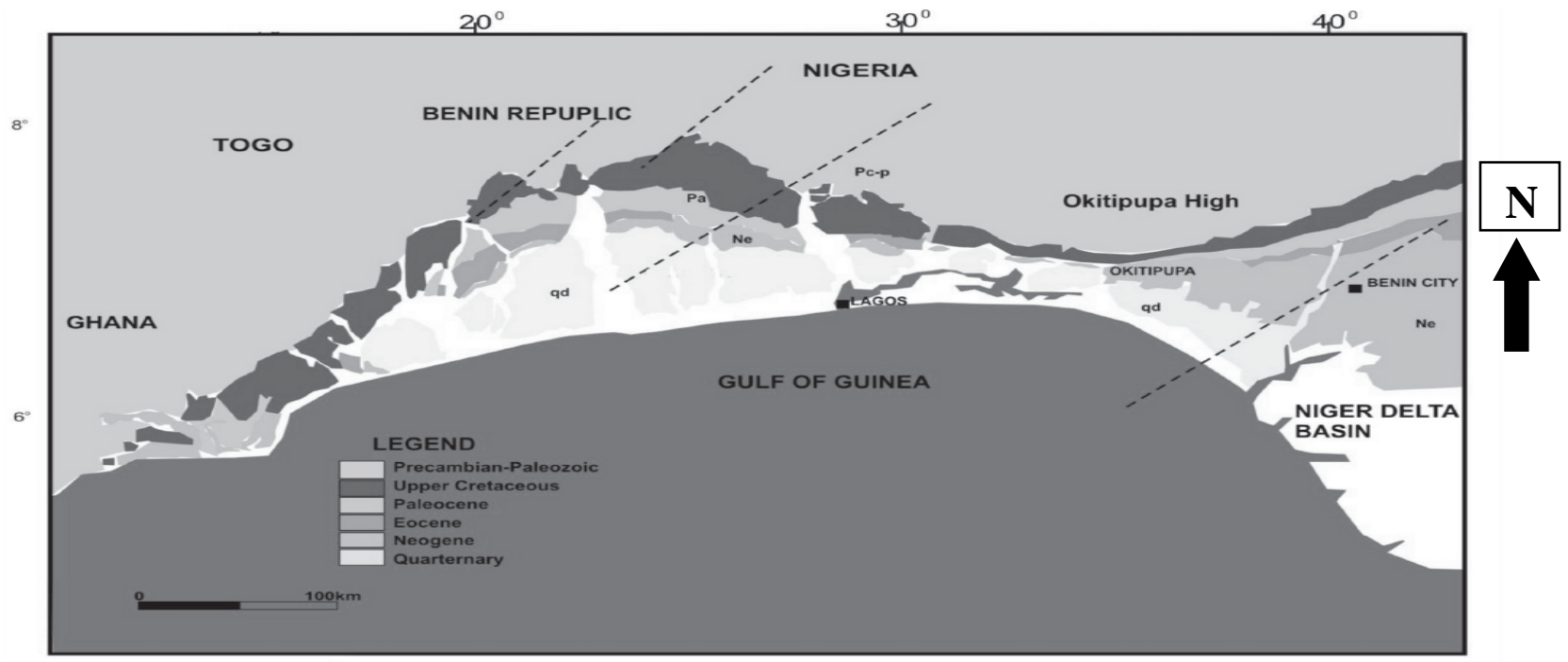

Fig. 1: General Geological Framework of Dahomey (Benin) Basin (After Omatsola and Adegoke, 1981).

\section{Materials and methods}

The core samples used for this study came from an exploratory well drilled in Ibese at latitude $6^{\circ} 58^{\prime} 0^{\prime \prime} \mathrm{N}$ and longitude $3^{\circ} 2^{\prime} 0^{\prime \prime}$ $\mathrm{E}$ as shown in Figure 3. The overall thickness of the drilled borehole is $30 \mathrm{~m}$, and the shale investigated in this study ranges from depth of $2 \mathrm{~m}$ to $19 \mathrm{~m}$. The shale samples investigated are dark grey in colour and are well laminated. A total number of 15 pulverized shale samples depicting the entire depth of the shale thickness in the well were selected based on their lithological characteristics and analyzed for their total organic carbon (TOC) content using the Walkley Black Wet Oxidation method. 1g of each shale sample was added to $10 \mathrm{ml}$ of $\mathrm{K}_{2} \mathrm{CrO}_{7}$ solution. Furthermore, $20 \mathrm{ml}$ of concentrated $\mathrm{H}_{2} \mathrm{SO}_{4}$ was added to it under a fume hood and swirled gently by hand. The beaker was left to stand for 5 minutes under the fume hood. Distilled water was added to the flask containing the solution to make the final volume approximately $125 \mathrm{ml}$, swirled gently and allowed to stand for 30minutes. 5 drops of phenanthroline complex $\left(\mathrm{C}_{12} \mathrm{H}_{8} \mathrm{~N}_{2}\right)$ were added and immediately titrated with ferrous sulphate solution. It was swirled gently and as the titration proceeds, the solution took on a green color that changed abruptly into reddish-brown when the end point was reached. Each volumetric reading was recorded, and the \% organic carbon present in the sample was calculated based on the volume of ferrous sulphate solution required to titrate the sample.

The generated TOC was further subjected to the Rock Eval II pyrolysis in Geomark Laboratory, Texas to deduce the organic matter type and hydrocarbon potential of the shale.

The TOC values of the shale samples analysed ranges from $0.96 \mathrm{wt} \%$ to $2.82 \mathrm{wt} \%$ and were all subjected to the Rock Eval pyrolysis. The pyrolysis oven was kept isothermally at $300^{\circ} \mathrm{C}$ for 3 minutes which caused the free hydrocarbons to be volatilized and measured as the $\mathrm{S} 1$ peak. The temperature was then increased to $550^{\circ} \mathrm{C}$ at $25^{\circ} \mathrm{C} / \mathrm{min}$, which is the phase of volatilization of very heavy hydrocarbons (>C40) as well as the cracking of non-volatile organic matter with the hydrocarbons released from this thermal cracking measured as the $\mathrm{S} 2$ peak. The $\mathrm{CO}_{2}$ issued from the kerogen cracking is trapped in the $300^{\circ} \mathrm{C}$ to $390^{\circ} \mathrm{C}$ range. It is heated, released and detected during the cooling of the pyrolysis oven and represented as S3 peak.

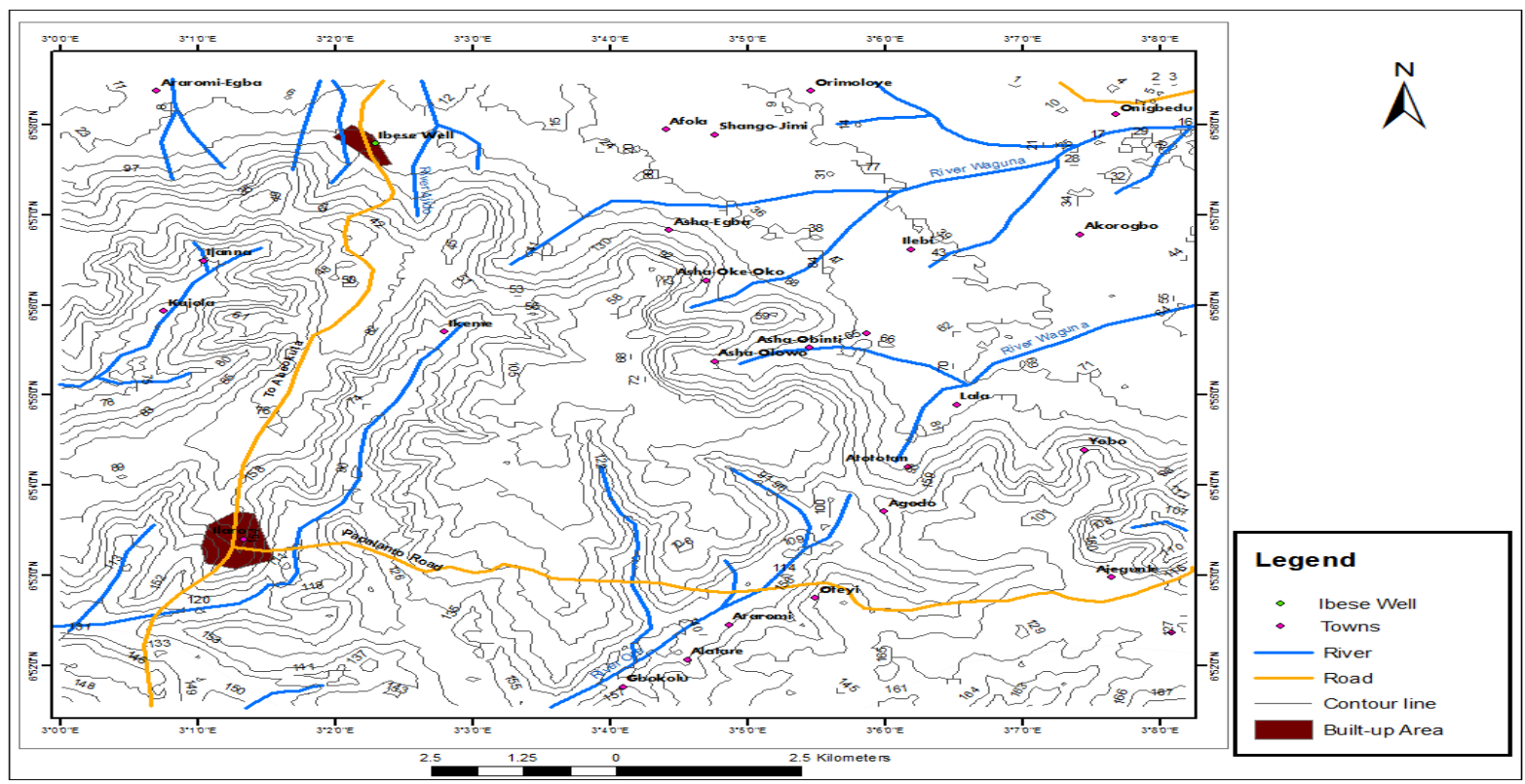

Fig. 2: Topographic Map Showing the Study Area. 


\section{Results}

Source rock evaluation must be based on the appraisal of multiple factors. In this study, the shale encountered at depth between $2.1 \mathrm{~m}-18.75 \mathrm{~m}$ as shown in Table 1 has TOC values ranging from 0.9 wt. $\%$ to $2.82 \mathrm{wt}$. \% with an average value of $1.67 \mathrm{wt}$. \% and thus, exceeds the threshold value of TOC $(0.5 \mathrm{wt}$. \%) required for clastic sediment to generate oil and gas (Tissot \& Welte, 1984 Unomah \& Ekweozor, 1993).

From the Rock eval pyrolysis, the basic parameters obtained after the work of Tissot and Welte (1984) include the S1 referring to the amount of free hydrocarbons (gas and oil) in the samples. The free oil content (S1) in the samples has values ranging from $0.07 \mathrm{mgHC} / \mathrm{g}$ to $0.17 \mathrm{mgHC} / \mathrm{g}$ as shown in Table 1 with a mean value of $0.11 \mathrm{mgHC} / \mathrm{g} .11 \mathrm{mgHC} / \mathrm{g}$. Though the values were relatively low, but it increases with depth. The values are relatively low and serve as an indication of the presence of gas as shown in Figure 4.

Another parameter that was also obtained from the pyrolysis is the $\mathrm{S} 2$ values. This indicates the quantity of hydrocarbons generated through thermal cracking of non-volatile organic matter. The source rock potential (S2) of the samples showed values ranging from $0.01 \mathrm{mgHC} / \mathrm{g}$ to $0.17 \mathrm{mgHC} / \mathrm{g}$ with an average value of $0.08 \mathrm{mgHC} / \mathrm{g}$. These values are equally low and indicative of poor source rock potential as presented in Figure 5.

S3, generated during the pyrolysis of the kerogen, which indicates the amount of $\mathrm{CO}_{2}$ produced, ranges from $0.26 \mathrm{mgCO}_{2} / \mathrm{g}$ to $0.46 \mathrm{mgCO}_{2} / \mathrm{g}$ and averages $0.29 \mathrm{mgCO}_{2} / \mathrm{g}$. This was used in calculating the Oxygen Index $(\mathrm{OI})$ which is the parameter that correlates the ratio of the Oxygen to Carbon in the sediment. For the samples analyzed the value as calculated from S3 ranges from $11.4 \mathrm{mgCO} / \mathrm{g}$ TOC to $38.33 \mathrm{mgCO} / \mathrm{g}$ TOC averaging $19.04 \mathrm{mgCO} / \mathrm{g}$ TOC.

The type of organic matter in the hydrocarbon source rocks was also characterized from the rock eval pyrolysis data and presented as Hydrogen Index (HI) which characterizes the origin of the organic matter. The values range from $0.44 \mathrm{mgHC} / \mathrm{g}$ TOC to $16.7 \mathrm{mgHC} / \mathrm{g}$ TOC, with a mean value of $5.77 \mathrm{mgHC} / \mathrm{g}$ TOC thus, suggesting gas prone sediment as established by the plot in Figure

While the values of Production Index (PI), which characterizes the evolution level of the organic matter ranges from 0.38 to 0.94 and averages 0.61 . The plot of the depth against PI shows that all the shale samples can only generate gas (Figure 8).

Table 1: TOC and Rock Eval Values of Akinbo Shale in Eastern Dahomey Basin

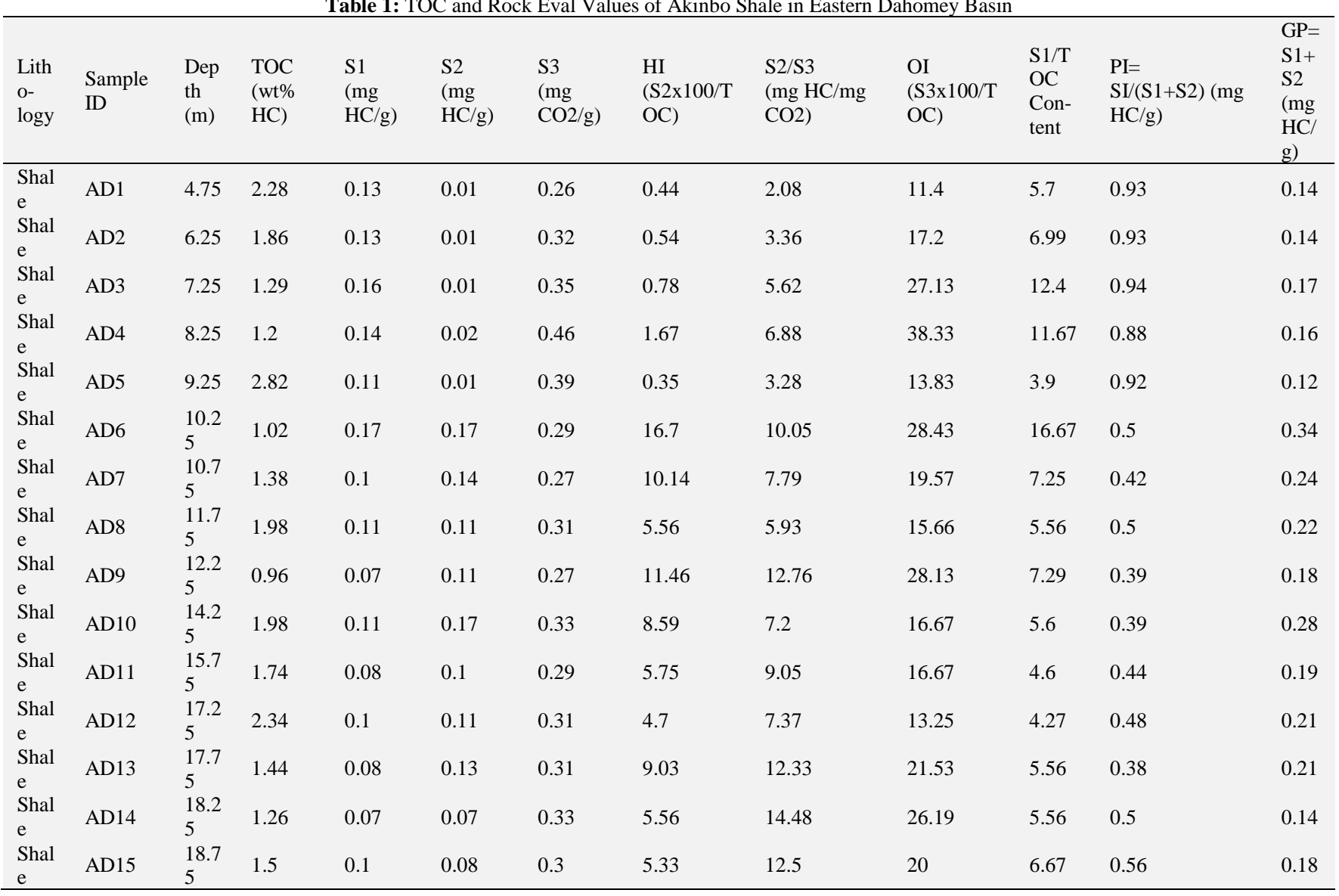




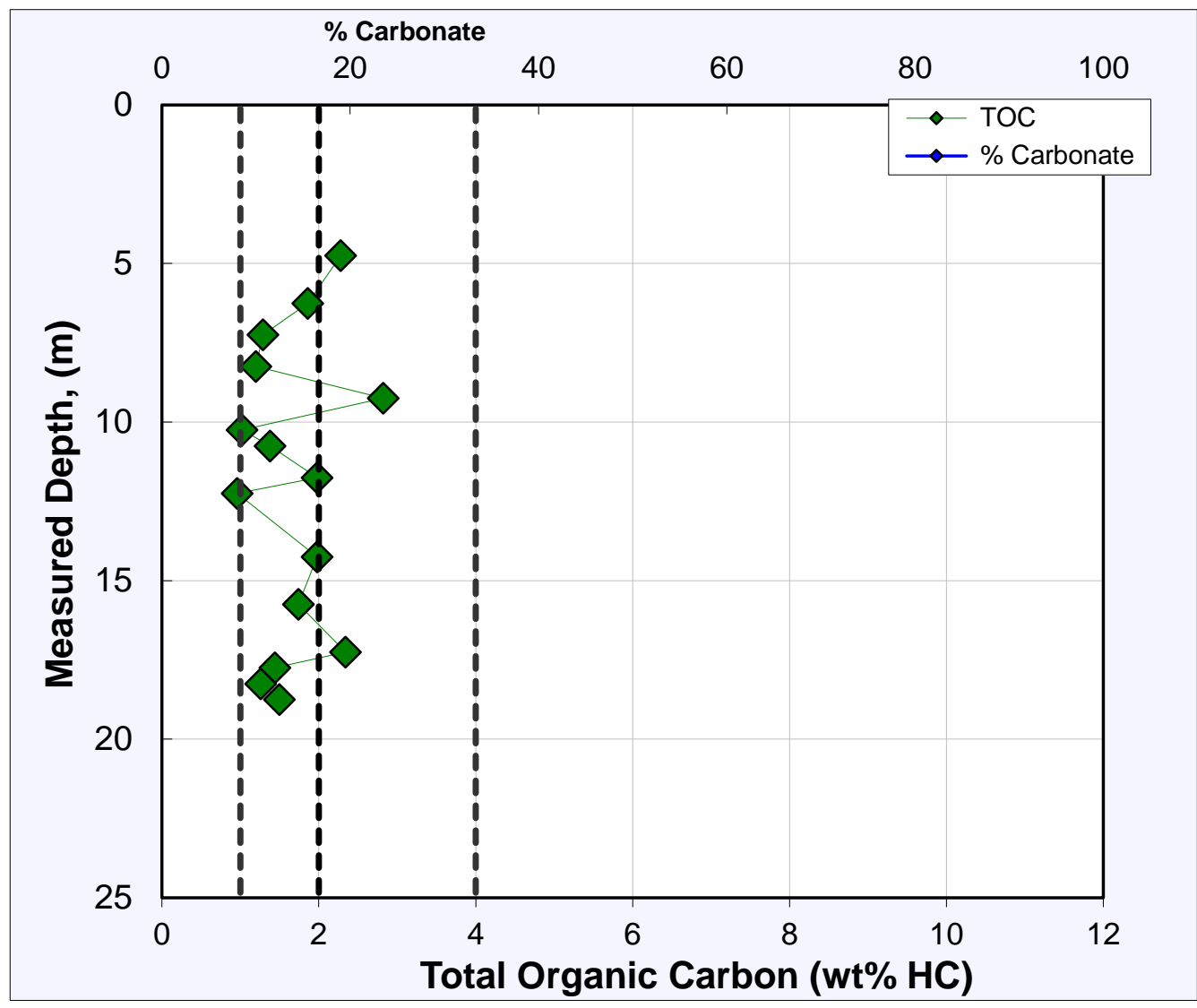

Fig. 3: Distribution of Total Organic Carbon for the Shale Samples.

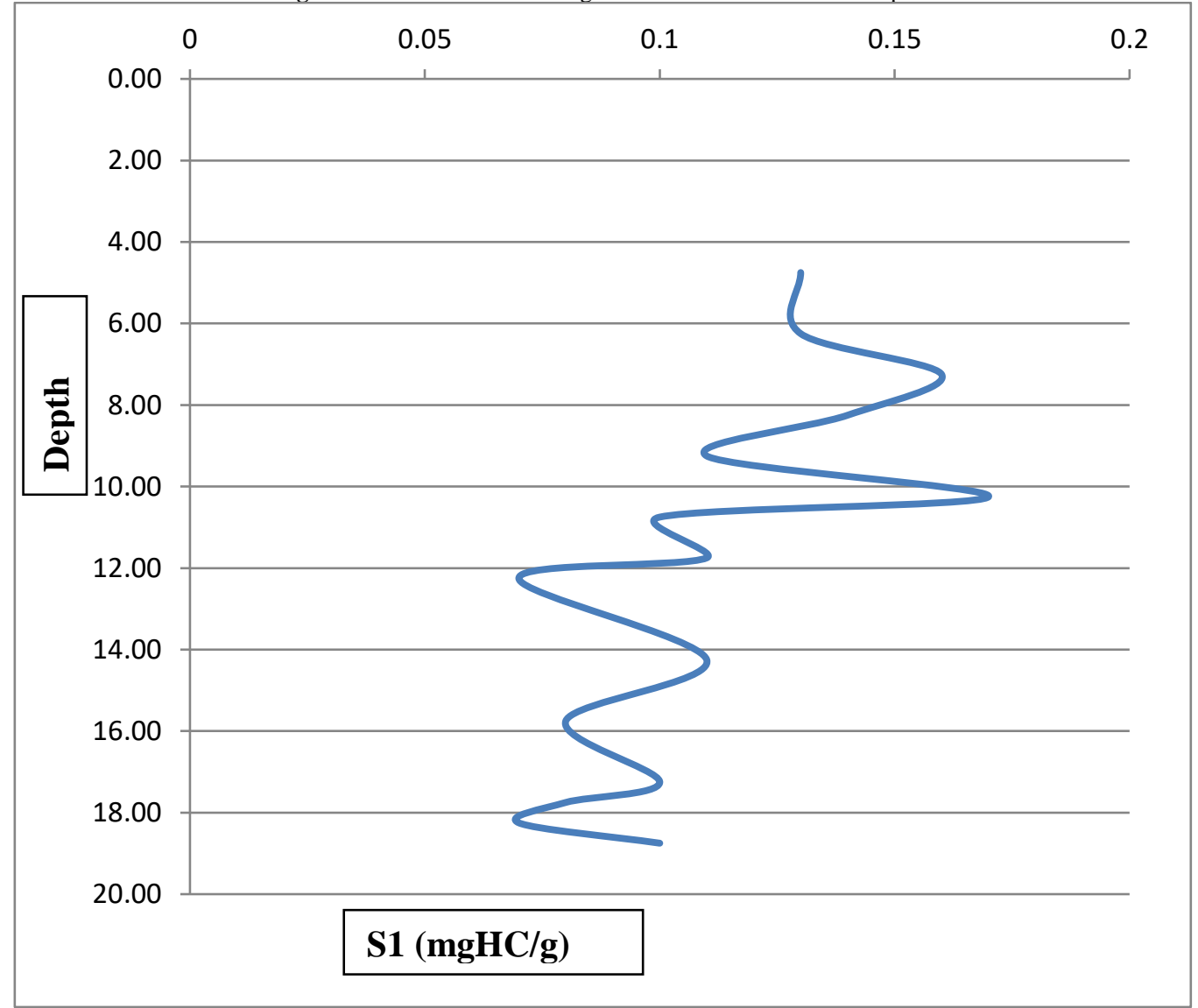

Fig. 4: Distribution of S1 for Shale Samples. 


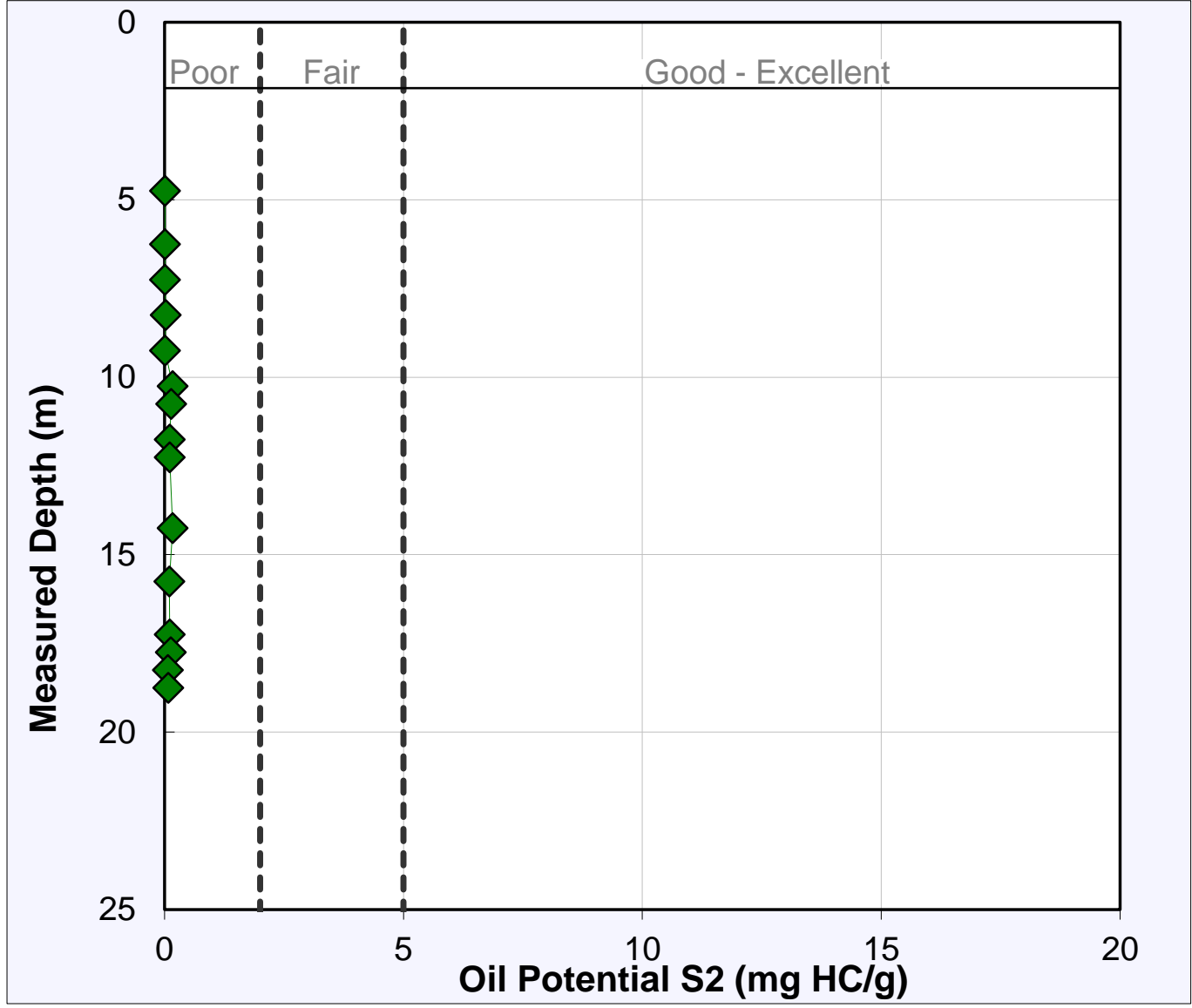

Fig. 5: Distribution of S2 Value for Shale Samples.

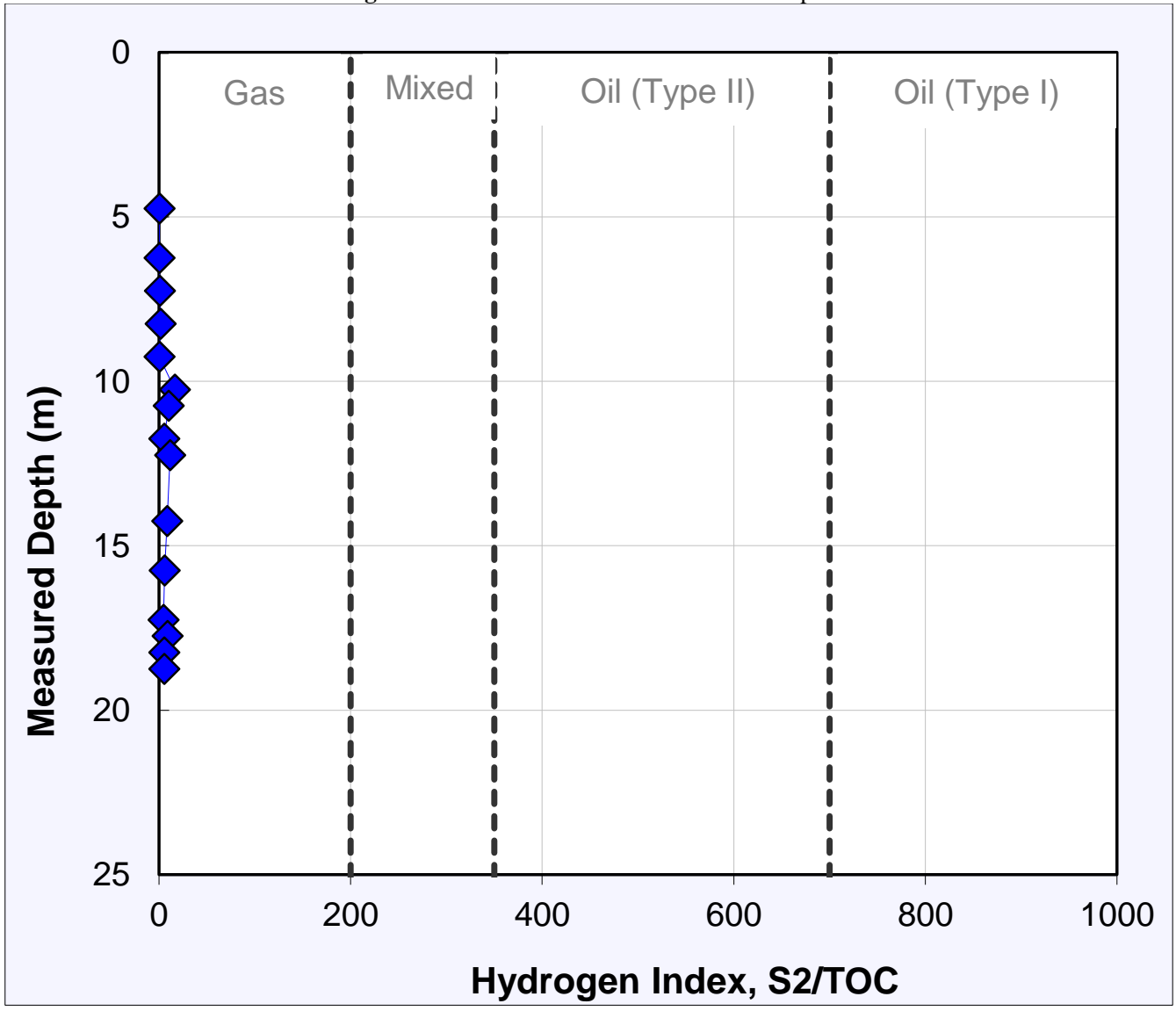

Fig. 6: Distribution of HI for the Shale Samples. 


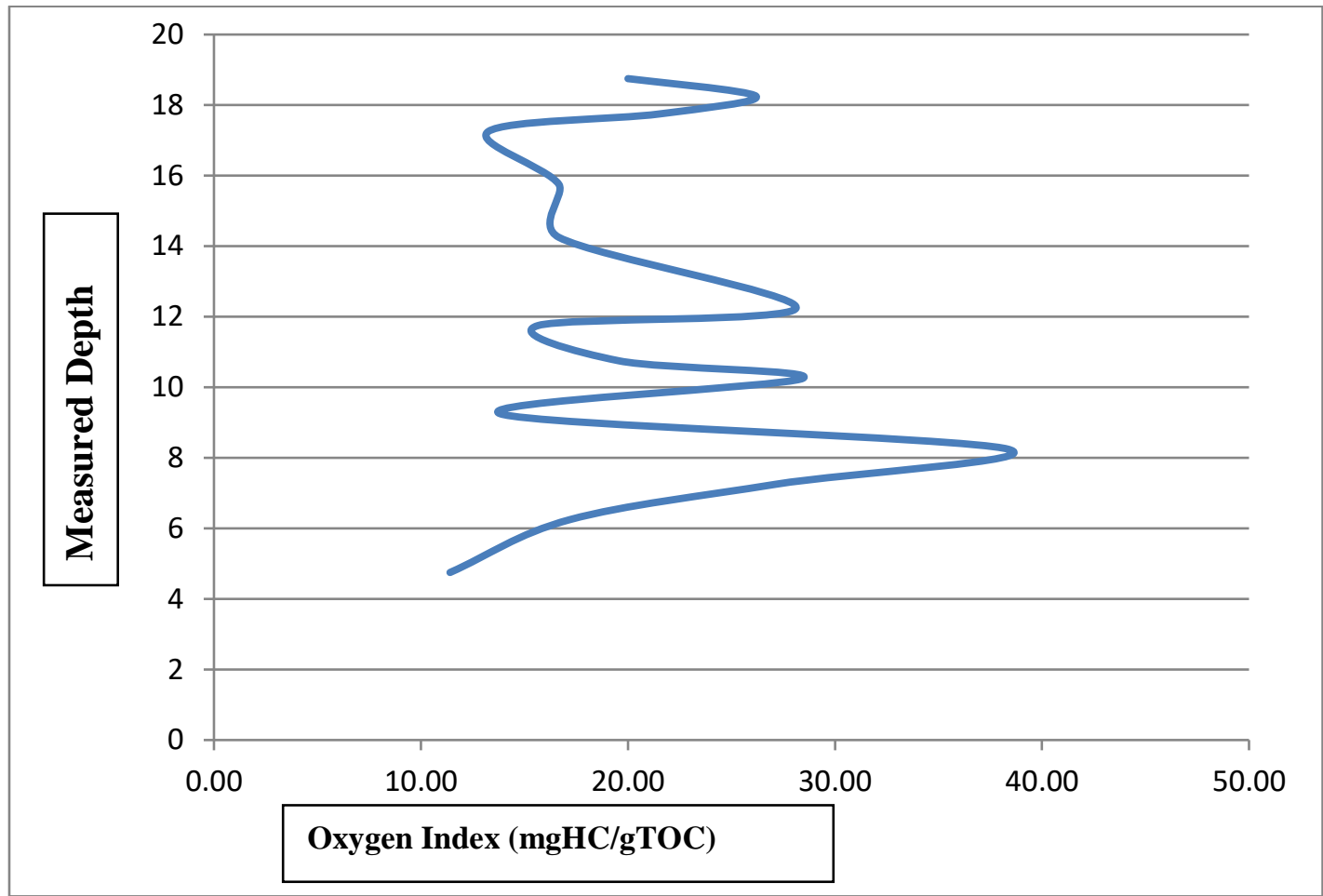

Fig. 7: Distribution of OI for the Shale Samples.

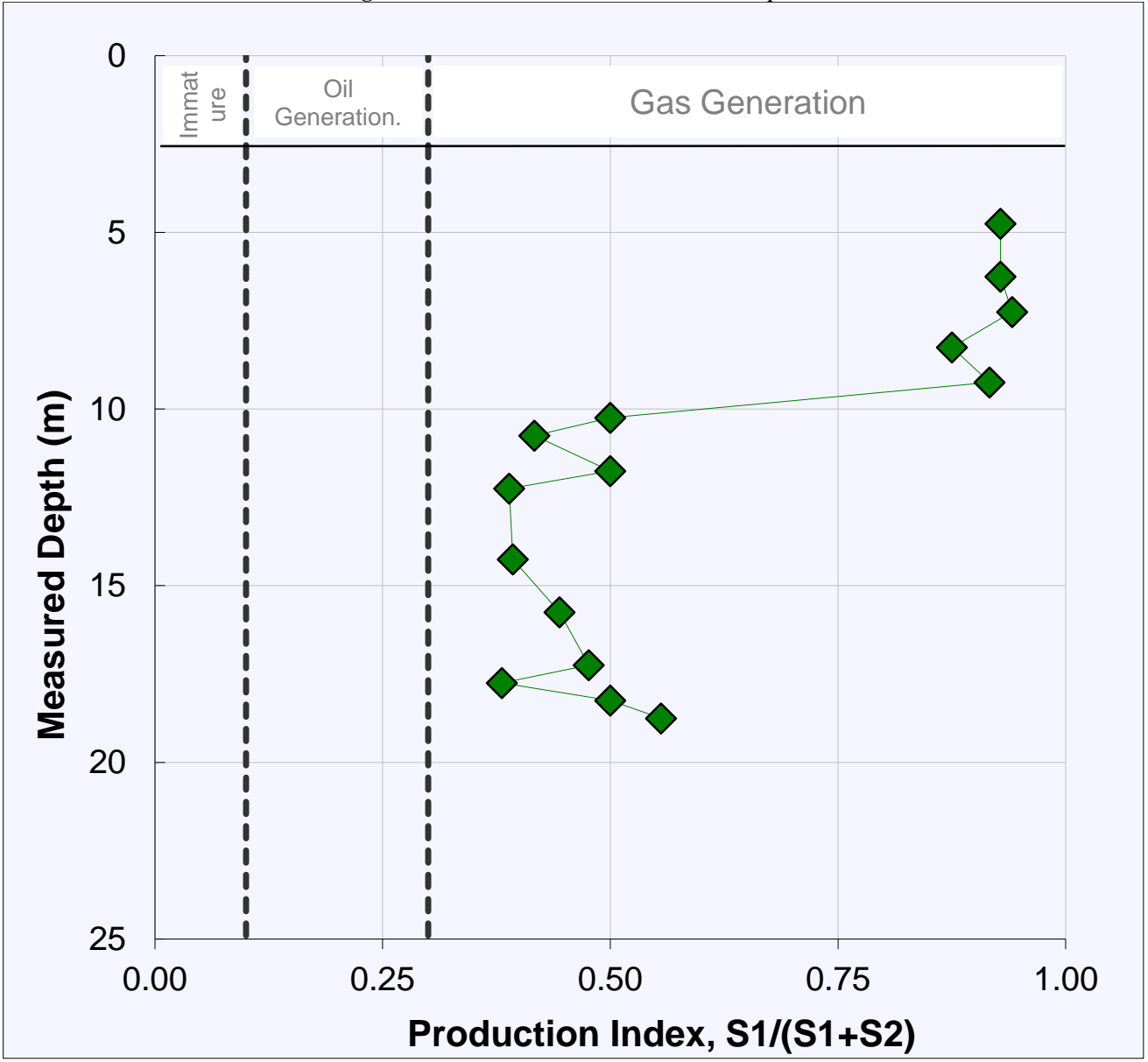

Fig. 8: Production Index Distribution of Shale Samples.

\section{Discussion of results}

\subsection{Organic matter richness}

Adequate organic matter measured as a percentage total organic content (TOC) is a necessary pre-requisite for sediment to generate oil and gas (Cornford, 1986). The TOC values of all the sam- ples analysed exceeds the threshold value of TOC (0. 5wt. \%) required for a clastic sediment to generate oil and gas (Tissot \& Welte, 1984; Unomah \& Ekweozor, 1993). The values indicate a source rock that range from poor in fair organic carbon content. This suggests that the Akinbo shale penetrated by the well has a fair amount of TOC to generate hydrocarbon. 


\subsection{Type and quality of organic matter}

In order to characterize the organic matter type (Kerogen type), in the hydrocarbon source rock, rock eval pyrolysis data was used and presented as HI and OI. These two indices are useful in tracking kerogen quality.

A modified Van Krevelen diagram showing a plot of HI against OI as displayed in Figure 9 shows a Type III kerogen. This is characterized by a low HI and fairly high OI. Thus, suggesting a woody or herbaceous organic matter origin. Peters, 1986, proposed that matured source rock, HI for a gas prone organic matters is lesser than 150, gas-oil prone, 150-300 while oil prone is greater than 300 . The values of HI as seen in Table 1 are relatively low, thus indicating an immature and gas prone source rock.

The crossplot of S2 versus TOC (Figure 10) indicates that the samples are dominantly liable to generate a dry gas.

\subsection{Hydrocarbon generating potential}

The Hydrogen Index (HI) values suggest source rock quality that spans from non-source potential through to gas generating potentials as shown in Figure 6.
The Rock-Eval pyrolysis data set with the derivatives determined from the programmed heating of samples in inert atmosphere provided evidence by direct estimation of the hydrocarbons that evolved freely (S1) and the hydrocarbons that can be generated directly from kerogen cracking (S2).

The values of S1 + S2 herein represent the rocks' total hydrocarbon generation potential (GP). From the assessment criteria of Dymann et al. (1996) and Akande et al (2002) who suggested that hydrocarbon yield $(\mathrm{S} 1+\mathrm{S} 2)$ less than $2 \mathrm{mg} \mathrm{HC} / \mathrm{g}$ rock typifies little or no oil potential (i.e has some potential for gas); $\mathrm{S} 1+\mathrm{S} 2$ from 2 to $6 \mathrm{mg} \mathrm{HC} / \mathrm{g}$ rock indicates moderate source rock potential and above $6 \mathrm{mg} \mathrm{HC} / \mathrm{g}$ rock suggests well to excellent source rock potential, the source potential value $(\mathrm{GP}=\mathrm{S} 1+\mathrm{S} 2)$ for the shale in the study area ranges from $0.12 \mathrm{mgHC} / \mathrm{g}$ to $0.48 \mathrm{mgHC} / \mathrm{g}$ TOC with a mean value of $0.19 \mathrm{mgHC} / \mathrm{g} 19 \mathrm{mgHC} / \mathrm{g}$ TOC; thus, indicative of little or no oil potential but with some potential for gas.

Also, the plot of TOC versus GP further proves the sediment is dominantly gas prone as shown in Figure 11 .

The absence of Tmax values for all the shale samples is as a result of the very low maximum evolution of the $\mathrm{S} 2$ peak values. This makes it impossible to determine reliable Tmax values, thereby making the source rocks to be immature.

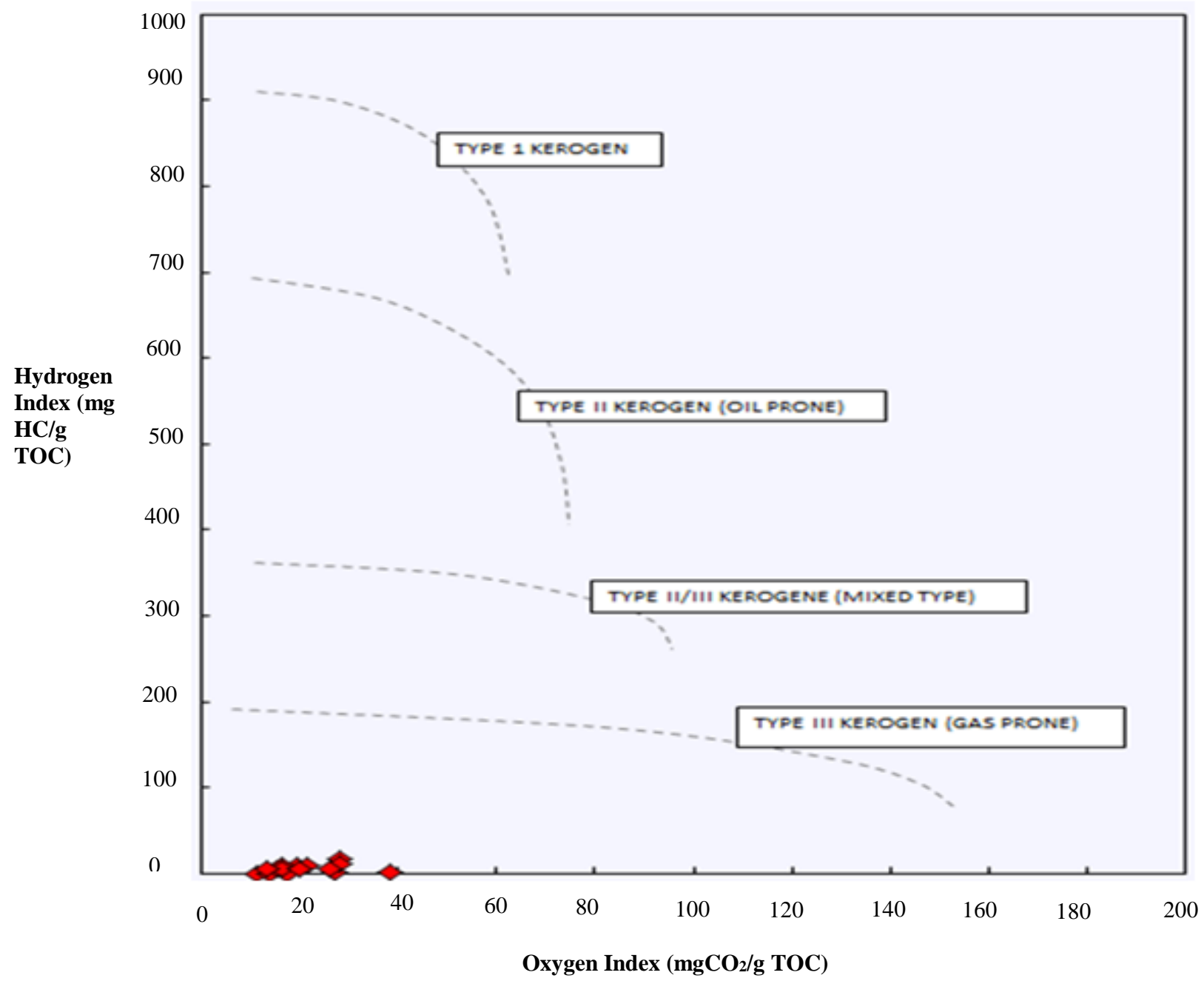

Fig. 9: The Plot of Hi Against Oi of the Shale Sample. 


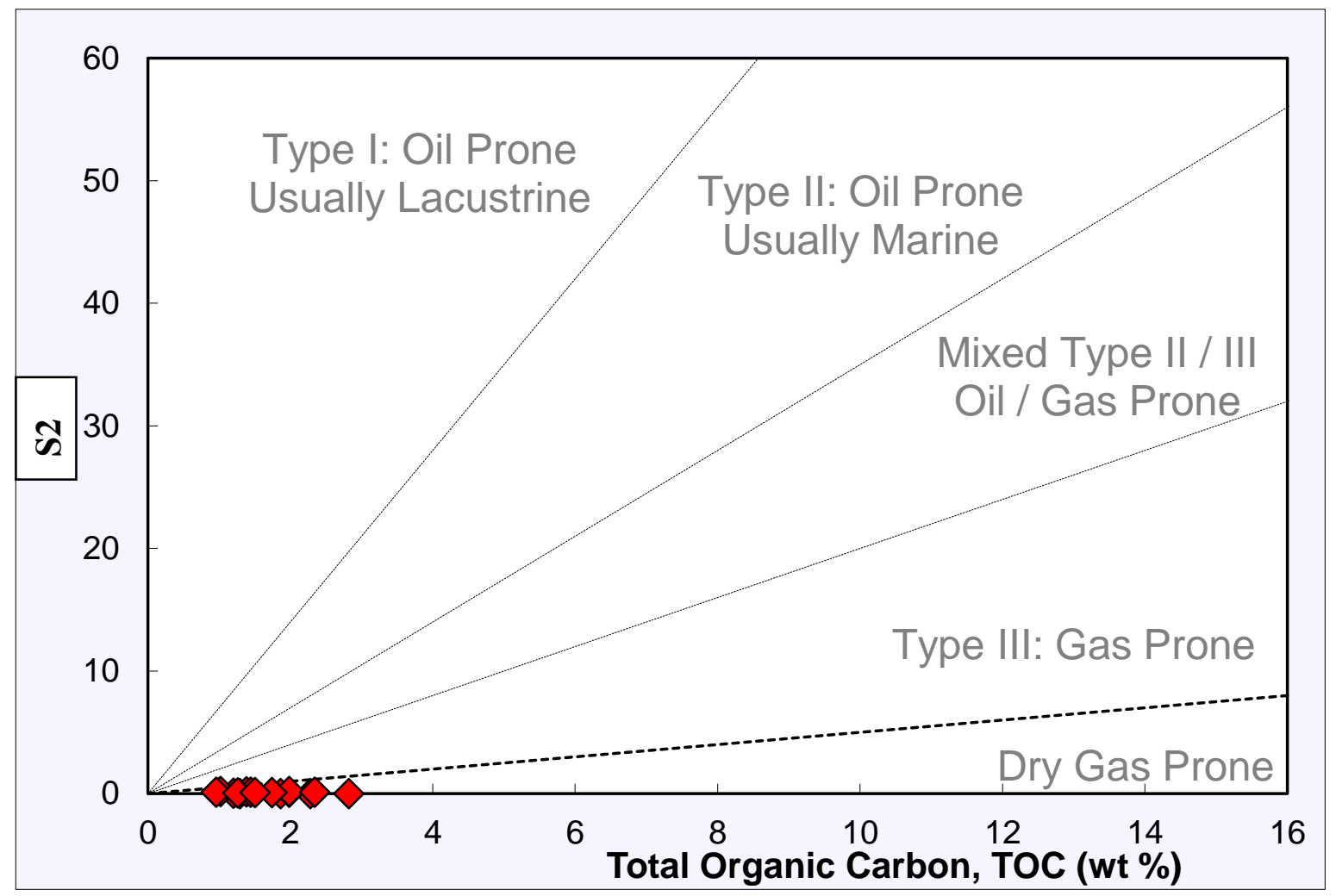

Fig.10: The Cross Plot of S2 Versus TOC of the Shale Samples.

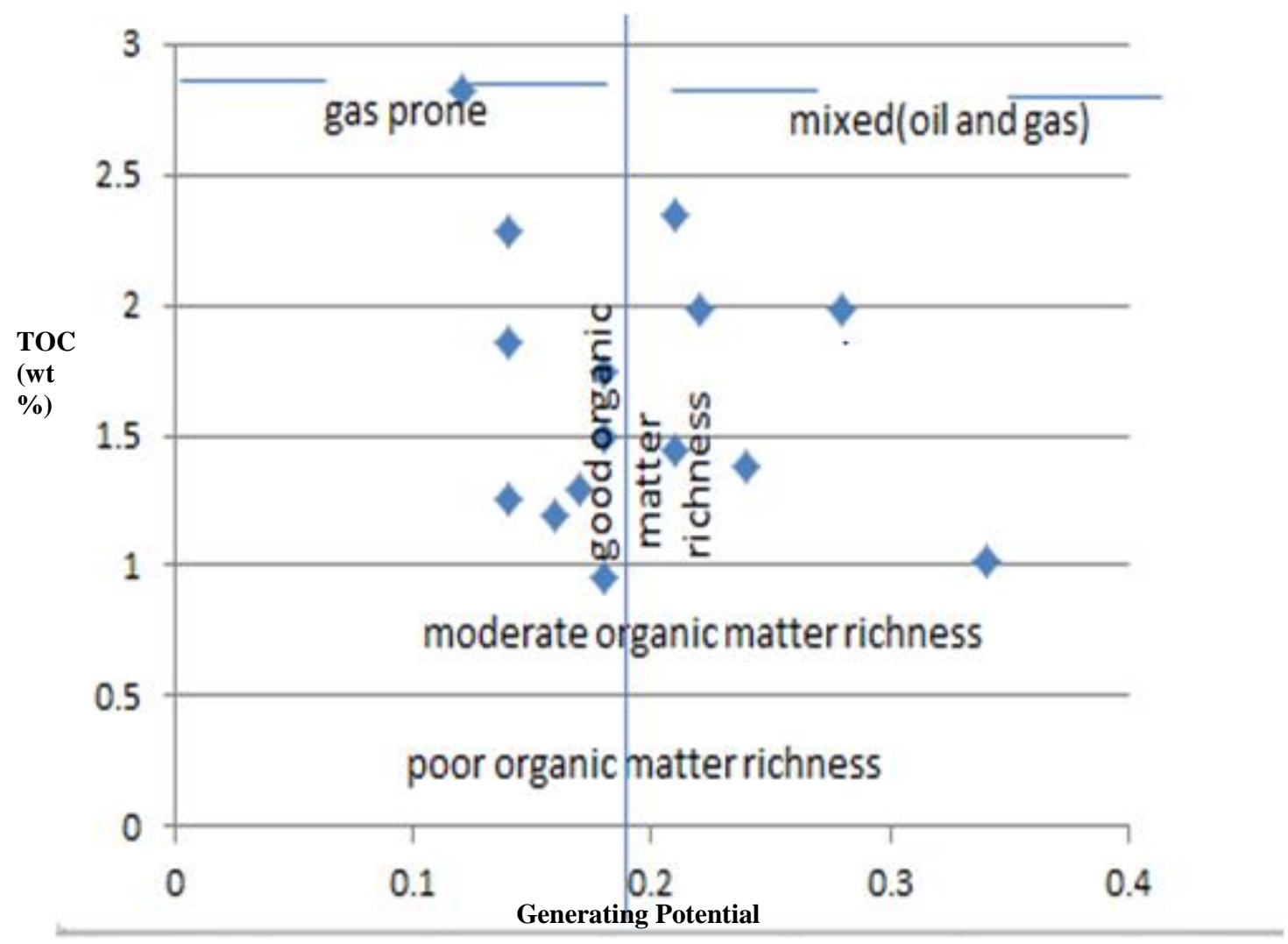

Fig. 11: Plot of TOC versus GP of the Akinbo Shale.

\section{Conclusion}

Shale sample from Akinbo formation was investigated to deduce the quantity and quality of the organic matter present in them, their hydrocarbon generating potential and kerogen type.

The Total Organic Carbon (TOC) of all the shale sampled averages $1.67 \mathrm{wt}$. \%; this exceeds the threshold value of $0.5 \mathrm{wt} \%$. Also, the plot of TOC against Generation Potential (GP) indicates good organic richness. Thus, indicative of a good amount of organic carbon in the sediments.

S1and S2 values for all the samples are relatively low and indicative of little or no oil potential and thus connote a poor source rock potential respectively. Also, the ratio of carbon to oxygen in the samples (S3), the hydrogen index (HI) and Production Indexes (PI) are indicative of gas prone sediments. 
Also, the plot of HI against OI shows that the shale samples belong to the Type III Kerogen which are sourced from woody or herbaceous plants and can only generate gas.

In conclusion, the Akinbo shale is gas prone and the organic matter present is sourced from a Type III kerogen which is still immature.

\section{References}

[1] Adegoke OS (1969) Eocene Stratigraphy of Southern Nigeria. Bur. Rech. Geol. Min. Mem., Vol. 69, pp. 23 - 43.

[2] Adekeye OA (2005) Eocene phosphates in the Dahomey Basin Journal of Mining and Geology, Vol, 17, pp. $99-106$.

[3] Adekeye OA, Akande OS, Bale RB \&Erdtmann BD (2006) Carbon and Oxygen isotopic compositions and diagenesis of the Ewekoro formation in the eastern Dahomey Basin southwestern Nigeria. Journal of Mining and Geology, Vol. 41 (1), pp. 87-95.

[4] Akande SO \& Ojo OJ (1992) Organnic petrology and rock eva studies on the source rock facies of the Campanian-Maastritchian Patti formation, southwestern Bida basin, Nigeria. Nigeria Association of Petroleum Explorationist Bulletin. Vol.16, pp.22-38.

[5] AkoBD, Adegoke OS \& Peters SW (1980) Stratigraphy of Oshosun formation in Southwestern Nigeria. Journal of Mining and Geology, Vol. 41. (1), pp. $87-95$.

[6] Conford C (1986) Source rocks and hydrocarbons of the North Sea In: Glennie. K.W., (Ed), Introduction to the Petroleum Geology of the North Sea. Oxford U.K., pp 197 - 236.

[7] DymanTS,Palacos JG, Tysdal RG, Perry WJ\&Pawlewicz MJ (1996)Source rock potential of middle cretaceous rocks in Southwestern Montana: AAPG bulletin, v.80, pp. 1177-1184.

[8] Jones HA \& Hockey RD (1964) The Geology of parts of southwestern Nigeria. Geological survey of Nigeria Bulletin, Vol. 31, pp 87.

[9] Kogbe CA (1974) Paleoecologic significance of vertebrate fossils in the Dukarnaje and Dange Formations (Maastritchtian and Paleocene) of northwestern Nigeria. Journal of Mining and geology, Vol.8, pp 49-55.

[10] Ogbe FGA (1970) Stratigraphy of exposed strata in the Ewekoro quarry western Nigeria. In: T.F.J. Dessauvagie and A.J. Whitemann (Eds.). African Geology, University of Ibadan press, pp. 305 - 324.

[11] Omatsola ME \& Adegoke OS (1981) Tectonic evolution and Cretaceous stratigraphy of the Dahomey basin. Journal of Mining and Geology, Vol. 18(1) pp. 130 - 137

[12] Peters KE (1986) "Guidelines for evaluating petroleum source rock using programmed analysis", The American Association of Petroleum Geologists Bulletin, vol. 70, pp. 318-329.

[13] Tissot BP \& Welte DH (1984) Petroleum Formation and Occurrence. 2nded. SpingerVerlag, Berlin 699p https://doi.org/10.1007/978-3-642-87813-8.

[14] Reyment RA (1965) Aspects of the Geology of Nigeria, University of Ibadan, Press, Ibadan, Nigeria. P. 145

[15] Unomah GI \& Ekweosor CM (1993) Petroleum source rock assessment of the CampanaianNkporo shale, lower Benue through, Nigeria. NAPE bulletin, Vol.8, No2, pp 172- 186

[16] Whiteman AJ (1982) Nigeria, its petroleum geology, resources and potential: Vols. 1 and 2, Graham and Trontman, Ltd., London, 394p. https://doi.org/10.1007/978-94-009-7361-9. 